\title{
External influences on agro-enterprise innovation platforms in Benin, Ghana and Mali - Options for effective responses
}

\author{
George O. Essegbey ${ }^{1, *}$, Owuraku Sakyi-Dawson ${ }^{2}$, Dansou Kossou ${ }^{3}$, Bara Ouologuem ${ }^{4}$, \\ Fidiala Dembele $^{5}$, Richard Adu-Acheampong ${ }^{6}$ and Janice Jiggins ${ }^{7}$ \\ ${ }^{1}$ Science and Technology Policy Research Institute (STEPRI), CSIR, P.O. Box CT 519, Accra, Ghana \\ ${ }^{2}$ Faculty of Agriculture, University of Ghana, Ghana, Legon \\ ${ }^{3}$ FSA, University of Abomey-Calavy, Akbakpa, Cotonou, Benin \\ ${ }^{4}$ IER, Sotuba, Mali \\ ${ }^{5}$ IPRI/ IFRA, Bamako, Mali \\ ${ }^{6}$ Cocoa Research Institute of Ghana, P. O. Box 8, Tafo-Akim, Ghana \\ ${ }^{7}$ Knowledge, Technology \& Innovation (KTI), WUR, Wageningen, The Netherlands
}

\begin{abstract}
This paper discusses external influences on innovation platforms (IPs) and the options for effective responses. The platforms examined in this paper were conceived as vehicles for facilitating institutional change in support of innovation that benefits smallholders, in selected agro-enterprise domains in Benin, Ghana and Mali. They were designed and implemented in a manner that enabled experimentation with processes of change in the selected domains. A Research Associate in each case facilitated the work of the IPs and applied TheoryGuided Process Tracing (TGPT) methodology to document the innovation processes pursued by platform members. The recorded data allow analysis of the external influences on the IPs. This paper first presents a typology as derived from literature of the main external influences on the domains of interest, and then uses the typology to analyse the influences on and responses of the IPs. The main influences were found to emanate from global, sub-regional and national levels. The IPs' responses were diverse but generally included reconstitution of the membership, lobbying, capacity-building among smallholders, and empowerment of smallholders by organizing provision of new knowledge, skills or financial resources. The paper highlights lessons drawn by the platform members in addressing the challenges involved. It concludes that external influences are important in determining the direction of socio-technical and institutional innovation.
\end{abstract}

Keywords: smallholder farmers and processors / institutional change / innovation

Résumé - Les influences externes sur les plate-formes d'innovation pour les entreprises agricoles au Benin, au Ghana et au Mali - Différentes options pour des réponses efficaces. Cet article analyse les facteurs externes influençant les plate-formes d'innovation (PI) et les différentes réactions possibles. Les plateformes étudiées dans cet article ont été conçues pour favoriser le changement institutionnel et l'innovation au profit des petits acteurs du secteur agricole au Bénin, au Ghana et au Mali. Elles ont été imaginées et mises en place de façon à pouvoir tester des processus de changement dans les domaines choisis. Dans chaque cas, un associé de recherche a facilité le travail de la PI et a mis en œuvre les théories du changement et a documenté les processus d'innovation élaborés par les membres de chaque plate-forme. Les données récoltées permettent l'analyse des facteurs externes influençant les PI. Dans un premier temps, cet article présente une typologie des influences externes majeures, pour ensuite utiliser cette même typologie afin d'analyser les influences sur les PI et leurs réactions face à ces facteurs externes. Les influences les plus importantes sont d'origine mondiale, sousrégionale, ainsi que nationale. Les réponses des PI ont été diverses ; elles incluent pour la plupart la recomposition des équipes, du lobbying, ainsi que l'augmentation de la capacité d'action des petits acteurs en facilitant l'accès aux aides financières et à de nouvelles connaissances et compétences. Cet article illustre les leçons tirées par les membres des plate-formes face aux défis rencontrés. On constate que les facteurs externes influencent de façon significative l'orientation de l'innovation sociotechnique et institutionnelle.

Mots clés : petits exploitants / agriculture familiale / transformations institutionnelles / innovation

\footnotetext{
${ }^{*}$ Auteur de correspondance : george_essegbey@yahoo.co.uk
} 


\section{Introduction}

Innovation does not occur in a vacuum. There is always a context and a multitude of actors in any innovation process, beyond those directly engaged (Falleti and Lynch 2009; Faure et al., 2010; Hall et al., 2006). The actors are exposed to diverse external influences, which affect their actions, decisions, choices and behaviours. The actors in turn respond to these external influences in various ways. However, a crucial question is how the actors respond to these external influences. In what ways do external influences matter in the innovation process? Do all actors respond to the external influences in the same manner? This article seeks to appreciate the way innovation happens in contexts and the effects of external influences on the domain of interest.

The article draws on the experiences and evidences documented by the Convergence of Science Strengthening Innovation Systems (COS-SIS) programme (2008-2013) (Hounkonou et al., 2012; Jiggins et al., 2016). In a prior programme phase, COS-1 (2001-2006), researchers worked with local groups of farmers, extension workers and crop specialists to develop socio-technologies that offered proven benefits in the local context, using a Participatory Technology Development approach (Röling et al., 2012). A follow up study provided strong evidence that the continued use and/or wider adoption of these local innovations had been constrained by institutions operating at a range of levels higher than the 'niches' in which they had been developed. The fundamental question driving COS-SIS thus was how to bring about institutional change at multiple scales that could sustain capacity for socio-technological innovations of benefit to smallholders (Adjei-Nsiah et al., 2013).

The COS-SIS programme supported the creation of Innovation Platforms (IPs) in eight agro-enterprise domains, in Benin (3), Ghana (2) and Mali (3) (Nederlof and Pyburn, 2012). The IPs' members sought to create space for stakeholders to address pertinent institutional constraints and opportunities in their domains. In each domain, the IPs first identified the institutional reasons why smallholders found it difficult to employ or derive benefit from existing or new socio-technical opportunities. They sought empirically-tested information on how selected institutions functioned and the institutional processes could be changed and by whom. The IPs conducted or commissioned field experiments and system-wide inquiries to generate new knowledge and information about transformative institutional changes in their respective domains. The initial memberships of the IPs included national policy makers, senior officials, research scientists, NGOs and civil society workers. Programme Management Teams (PMT) comprising of representatives from traditional authorities, farmers, academic and research institutions and the ministry responsible for agriculture in each country included key actors positioned at national levels in the respective domains of interest.

The critical points of departure for this paper are the nature, character and thrust of the external influences on the IPs. The specific objectives are to:

- define and elaborate the "external influences" in selected cases from literature;

- create a typology of the external influences identified and analyse their influences on the operations of the different platforms;
- discuss platform responses in order to establish broad patterns and draw lessons for effective responses;

- it is intended also to contribute to understanding of the term 'external influences'. Neither the relevant literature, nor common usage, has settled as yet on a clear definition.

This paper is organized as follows: the next section presents the key concepts applied in the analysis, followed by the methodology, and the main findings and analysis. The discussion highlights the main propositions identified by the analysis. The concluding section underscores the key messages of the paper.

\section{The concepts}

This section first presents a preliminary clarification of the key concepts used in the article and then describes how the external influences identified have been framed. A typology is introduced that is used to analyze their influences on the IPs.

Innovation in this paper is understood as a successful combination of hardware (the equipment), software (the idea) and orgware (the embedment) of an intentional change, viewed from a societal and/or economic point of view (Dobrov, 1979). Hardware is simply the physical embodiment of the innovation; software refers to "new ways of thinking" and "mindsets" (Leeuwis and Van Den Ban, 2004); orgware is the organizational and institutional conditions of the innovation. In this perspective, it is the way that all three interact that determines the success of innovation.

Institutions have been defined as the informal and formal rules and regulations that govern human action (Douglas, 1986; North, 1990). The informal rules which are not enshrined in national laws but are those pertaining for example to people's norms, culture, religion and ethics. The formal rules are enshrined in legislations and regulations. Williamson (2000) framed institutions as the rules of the game, expressed in terms of embedded norms and values, legislative and regulatory frameworks, policies and negotiated agreements that govern individual behavior. Geels (2004) explains the importance of institutions in innovation by reference to its normative, regulative and cognitive dimensions. In putting these perspectives on institutions together, this article understands that the enabling environment within which the innovation platforms examined in this article operate, are created by the decisions, activities and behaviours of actors in public and private, formal and informal institutions.

The concept of institution relates to the concept of innovation in various ways. For example, innovation projects the picture of a bounded system of interactions as defined by institutions. The interactions are important in bringing new things into use or addressing contextual constraints. The system of interest here is defined as "the network of organisations, enterprises and individuals focused on bringing new products, new processes, and new forms of organisation into economic use, together with institutions and policies that affect their behavior and performance" (Hall et al., 2006, p. 16). An 'innovation system' thus embraces the totality of interacting actors, and the factors affecting demand for creation and use of knowledge in novel and useful ways. The role of facilitators is also important in stimulating innovation in 


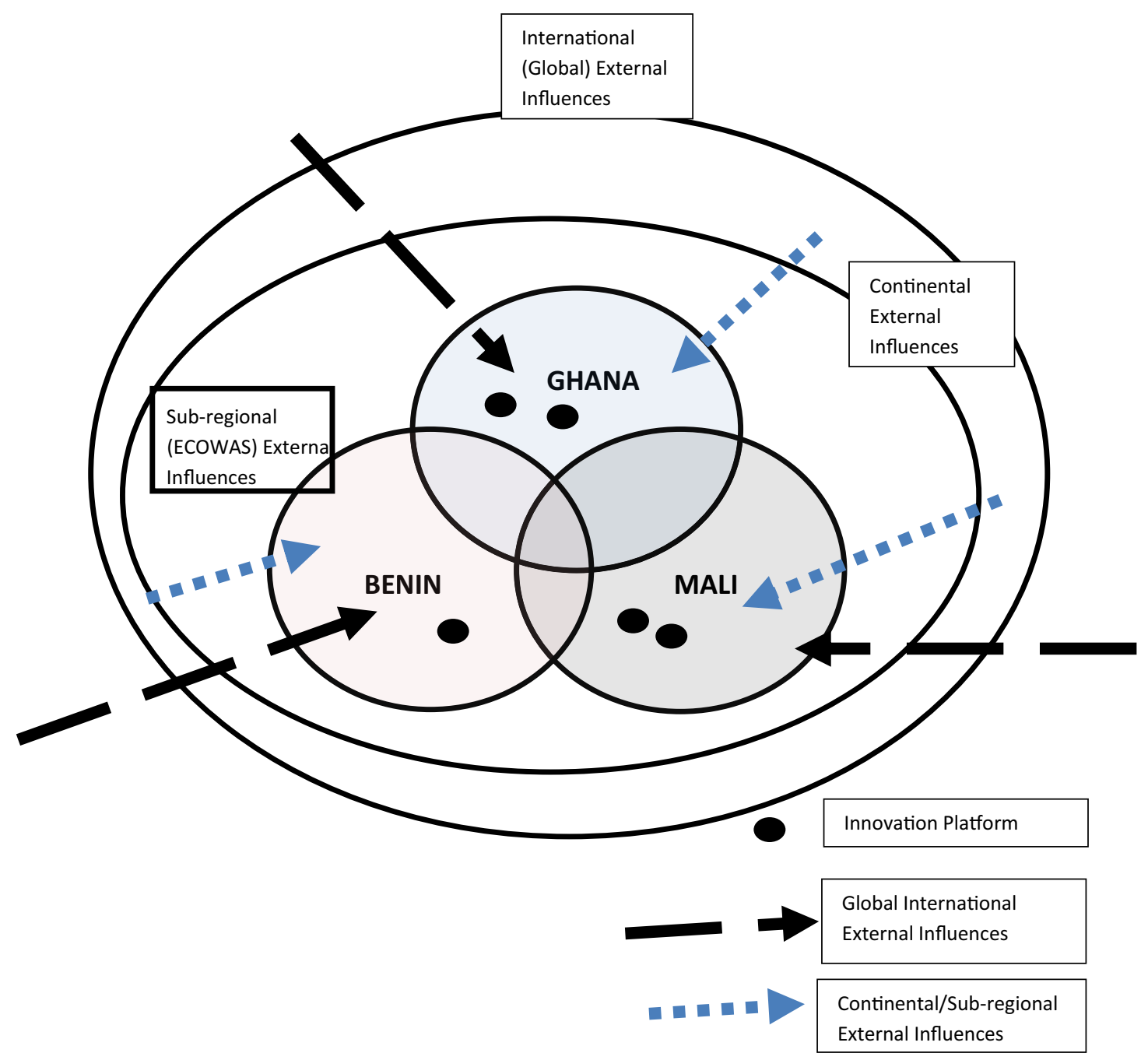

Fig. 1. Diagrammatic illustration of the framework of external influences. Source: derived by the authors from analysis of RA's and National Coordinators' process narrative reports, every 4 months, 2011-2013.

networks, partnerships, and other collective arrangements (Hawkins et al., 2009; Faure et al., 2010; Nederlof et al., 2011).

The IPs treated here operated in identifiable institutional regimes. A regime as a stabilized set of relationships, procedures, practices, rules, norms and so on, is not predisposed to innovation. The concept of niche applies in this paper and a 'niche' means an 'incubation space' characterised by experimental disorder (Geels, 2002). In order to effect significant changes in a regime, an IP has to be able to develop a pathway through which the effective outcomes of 'niche experiments' can radically alter, or by-pass, a sub-set of, or even the entire institutional regime - a pathway that is often resisted by those benefiting from the prevailing regime (Beuret et al., 2006).

External influences affect innovation and institutions in various ways and this article, in the subsequent sections, will illustrate and discuss this. External influences generally come from outside of the domains or specific localities of innovations. They may be national and therefore within the respective country; they may be coming from the sub-region or continental, or the external influences may be coming from global sources. The connections between the concepts of external influences, innovation platforms and institutions are better illustrated in Figure 1 in the summary of the Methodology section. Table 1 also summarizes the types of external influences in the analysis. The external influences on the work of an IP, in this perspective, demand responses, which have to be appropriate and effective. In the three countries included in the COS-SIS programme (namely Benin, Ghana and Mali), institutional regimes tend to be highly vulnerable to the range of external influences, especially political external influences. The type of external influence largely dictates the responses from the innovation platform. The subsequent sections elaborate on this.

\section{Methodology}

For Benin, the domains were water/rice resource management in the inland valleys, oil palm seedling nurseries, and cotton. For Mali, the domains were crop/livestock integration, and water resources management (both located in the large 
Table 1. Summary of main external influences on the IPs.

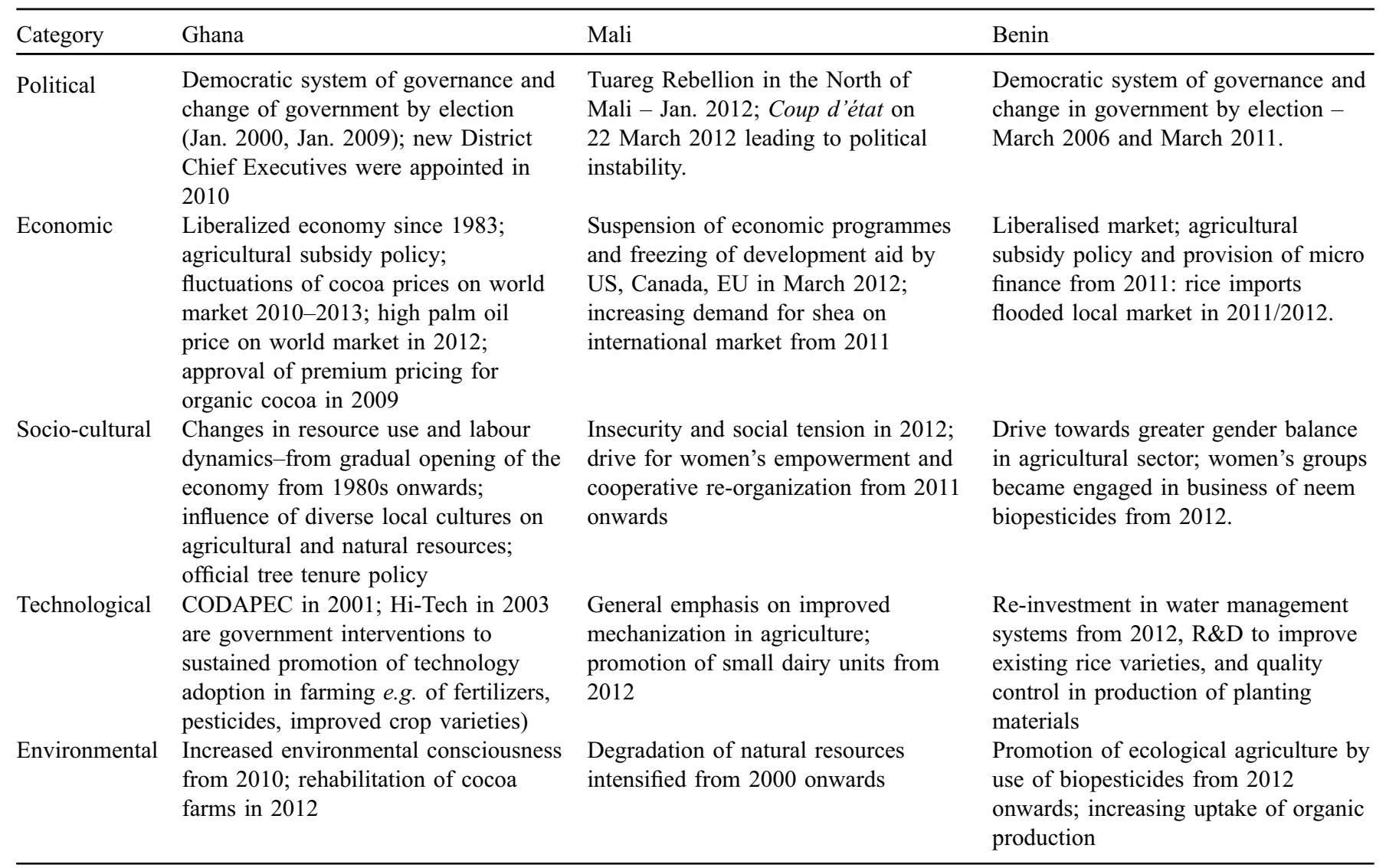

Source: Authors' construct, from analysis of TGPT data, January 2011-December 2014.

Notes: CODAPEC - National Cocoa Diseases and Pest Control; Hi-Tech Programme was designed to promote the use of fertilizer and improved seedlings.

scale irrigation scheme, the "Office du Niger" - ON), and development by women's cooperatives of shea nut value chains. For Ghana, the domains initially selected were oil palm, food security and cocoa. For various reasons, the food security domain was dropped after about 18 months. The studies conducted in all the domains in the three countries vary in the degree of successful completion. However, each study discussed in this paper provides sufficient basis for analysis.

The design of this study is based on within-case and between-case analysis of the data set outlined in Jiggins et al. (2016). The framework applied in this study focuses on significant external influences identified in the literature. These are seen as originating in three arenas, as depicted in Figure 1, namely the national context, the continental or sub-regional, and the global arenas.

The external influences emanating from the national context tend to be the most recognizable and the most pressing on the IPs. They include:

- economic developments, social organisation, political dispensation and cultural norms and traditions;

- the mix of national plans, policies, programmes and sectoral policies;

- the specific attributes of the agro-enterprise value chains and networks operating in each of the domains.
Secondly, continental and sub-regional influences such as those emanating from Economic Community of West Africa States (ECOWAS) negotiations on trade matters, affect domain opportunities. Thirdly, the influence of the world powers, expressed in multi-lateral and bilateral relationships, treaties and conventions, has a more distant but palpable effect. In this article, these three scales of interaction, and the types of influence characteristic of each scale, are used to structure a typology that is then applied to frame the analysis.

The authors of this paper (who acted variously as RAs and National Coordinators throughout the study period) subsequently (i) manually re-analysed the data assembled in all programme materials, to identify external influences and the IPs' responses, by sorting and coding dominant influences; (ii) interviewed in-depth in December 2013-March 2014 three of the Ph.D. students (who had gained their doctorates in December 2013), to capture their experience of the identified influences; (iii) developed from the relevant literature as discussed in the section "The concepts" above, the three-scale typology presented above; and (iv) applied the typology to the information generated by (i) and (ii). One may regard the typology as an initial typology for sorting and discussing the findings of the data sets and case studies of the individual IPs. We, the authors, discussed the external influences as identified 
in the case studies and on the basis of the analysis developed the typology in Table 1.

\section{Findings and analysis}

Indeed, we have identified five main types of external influences on the work of the IPs: political, economic, sociocultural, technological and environmental. Table 1, based on the Theory-Guided Process Tracing (TGPT) records, summarises the main influences on the work of the IPs, categorized by type. In the social sciences, TGPT is a useful method for gathering, analyzing data and drawing conclusions about events and situations (Beach and Pedersen, 2013; Blatter and Haverland, 2014).

The preceding section has highlighted in broad strokes the external influences on the IPs. Below are the mini-cases of the specific IPs set up in the three countries. In Ghana, there were two IPs. There was the Cocoa IP set up to address the specific institutional constraint of cocoa pricing. There was also the Oil Palm IP, which addressed the challenge of entering the export market by smallholders. In Mali, the case studies of the two IPs on shea nut and livestock-crop integration highlight how important political external influences can be in the innovation process. And in Benin, the rice/water management IP also illustrates how institutional linkages can be fundamental in bringing about innovation. We now examine how the IPs responded, by elaborating the five mini cases in the three countries.

\subsection{Cocoa IP, Ghana}

Adu-Acheampong et al. (2017) describe how for many years cocoa has played a significant role in the politics of Ghana. The sector is governed by a public agency, the Ghana Cocoa Board (COCOBOD) that occupies a prominent position in the political hierarchy. COCOBOD in 2008/ 2009 decided to register private sector enterprises to trade in organic fair trade cocoa. Yayra Glover, and its partner Felchlin of Switzerland, became the first organic fair trade Licensed Cocoa Buying Company to be registered by the Board, an example of political decisions that created opportunities for change in the cocoa industry. The IP in 2010-2011 responded by carrying out an analysis of available data on cocoa prices together with the Cocoa Organic Farmers Association (COFA). It then supported paying organic farmers a premium price of $\$ 600$ per metric ton. The IP then linked COFA to Yayra Glover so that the smallholder farmer members in addition to receiving agricultural advisory services could benefit from the premium pricing. The IP assembled experiment-based data to support the case for preferential pricing, to encourage delivery of quality beans (Adu-Acheampong, 2013; Quarmine et al., 2012).

\subsection{Palm oil IP, Ghana}

Adjei-Nsiah and Klerkx (2016) trace the successive decisions and activities of this IP, established in the Kwaebibrim District in 2010. Fresh space for this IP opened when national elections in January 2010 brought a new government to power. At the beginning of 2011 the IP suspended its operations while the new administration settled in and a new District Chief Executive was appointed. Thereafter, the IP's membership was re-constituted to take account of the new local government context. During the period of the study the world market for palm oil increased. However, in 2012 local producers preferred to sell on the local market because the local market price was higher than the global market price $-\$ 800$ per metric ton, compared to $\$ 700$ per metric ton on the world market, although the export market potentially offered the advantages of assured demand and scale expansion. The IP, in discussion with the women oil palm producers in the district, decided to explore the potential for exporting into the world market. They identified four main challenges:

- meeting the quality requirements;

- assuring supply of the volume required;

- finding an export partner;

- negotiating a remunerative supply price (Adjei-Nsiah et al., 2013).

The Ph.D. student, with the encouragement of the IP, already had demonstrated that the women processors could supply quality palm oil (Osei-Amponsah, 2013). A potential export buyer was identified but the initial negotiations broke down because the women stood out for too high a price, could not guarantee the volume demanded, and local markets still offered easy profit to the processors. Subsequently, under threat of losing the domestic market because of the introduction of mechanized processing mills, the women decided to organize themselves throughout the district in order to secure a loan to purchase their own mechanized equipment from the Ghana Export Promotion Authority. There were negotiations with the exporters over supply volumes, delivery schedules and the prices. The women resumed business with exporters in 2013 (Adjei-Nsiah et al., 2012).

\subsection{The shea nut IP, Mali}

The shea industry is predominantly a smallholder concern. It relies on harvesting the fruits of shea trees growing freely in the landscape. Shea processors usually need to take loans to be able to buy shea nuts from the harvesters. Increased demand for shea products in regional and international markets led the IP to help women's apex co-operative to secure credit for its member cooperatives in 2012 (see Sidibé et al., 2017). The shea nut co-operatives were specialised, some concentrating on packaging butter processed by women's groups for export, others processing the nuts themselves and selling the packaged butter on domestic and regional markets. The technological content of the value chain is rather low. The advantage of the low technology threshold is that large numbers of poor women can become involved in the value chain. The disadvantage is the inefficiency of butter extraction and the effect on product quality. The IP in 2013 began discussing with the apex cooperative the promotion of improved technologies such as energy efficient stoves. Here we note how the domain as a whole, and the emergent shea industry, was impacted negatively by the most pronounced political event in Mali during the implementation of the COS-SIS programme. This was the coup d'état and the rebellion in the north of the country that broke out in 2012. It disrupted commercial activities in 
much of the savannah area and changed relationships between central and local government. Within the shea domain, internal political influences also played an important role. Notably, the President of the Commission of Research Users of Bamako and Koulikoro became in 2012 the President of the National Commission of Research Results Users of Mali as well as the Vice President of the Permanent Assembly of Agricultural Chambers of Mali. The move by this individual into a strong position of influence changed the relationship between the shea nut IP and the Permanent Assembly of the Agriculture Chambers of Mali, allowing a more harmonious relationship to develop between the co-operative organisations of the women shea nut producers and the shea nut exporters, who are the big players' in the domain.

\subsection{The livestock-crop integration IP, Mali}

The achievements of this IP are analysed by Ouologuem et al. (this issue). We here note first the IP's response to the introduction by the government in 2011 of a fertilizer subsidy. Because only farmers who were members of a farmer-based organization had access to the subsidy, the IP encouraged the revitalisation of farmer-based organizations in the villages where it was working. The IP organized a workshop to train farmers in financial management, encourage farmers to store their harvest until later in the year when the price for rice went up, and to use sales of milk and meat to smooth their income through the year.

However, as the rebels moved southwards in 2012 towards the banks of the Niger river, the disturbances affected the IP's operations directly. The rebels came as far as Diabali, about $45 \mathrm{~km}$ from the research station of the Institute for Rural Economy (IER) at Niono, where the IP's operations in three study villages were coordinated, and within $10 \mathrm{~km}$ of another research station in Kogoni that also was cooperating with the IP. In the general conditions of insecurity, the IP halted its work. People fled from their villages to escape the rebels and the breakdown of social order. The cattle herded by pastoralists were moved back for safety into the irrigated areas administered by the $\mathrm{ON}$ earlier than normal, and in the process much of the as yet un-harvested crop was destroyed. In 2013 the IP resumed its activities.

\subsection{Rice/water management in inland valleys IP, Benin}

The rice industry in Benin is politically important because rice has become the main food staple of urban populations. In the past, local foods were primarily based on maize, cassava and sorghum. However, since the 1990s, when rice imports increased, there has been a gradual shift to rice creating new opportunities for small holder rice farmers, input suppliers, processors and rice importers. Vested interests in both the public and private sectors struggle to guard their powers to control rice pricing and key points of the domestic production and import value chains, as the following examples illustrate:

- when conflict erupted in 2012 between government and the input supplier, farmers experienced a severe fertilizer shortage. Restoration of input supply and fertiliser distribution clearly demanded institutional change. The
IP contacted decision makers in the Ministry of Agriculture and deliberated with them on how to address the issue. The immediate response of the government was politically expedient but not entirely successful in ensuring rice farmers secure access to fertilizer at an affordable price;

- the domestic rice market is price-responsive. In June 2012, because of the release onto the market of cheap rice imports, there was a slump in demand for domestic rice, bringing the price down by about $50 \%$. The IP responded by initiating activities to diversify the rice market for smallholders, for example, by developing a value chain for branded rice, and launching packaged parboiled rice products (Saidou et al., 2012; Totin et al., 2012; Totin et al., 2014a);

- local rice has suffered in competition with imports also because of its poor quality. The IP initiated in November 2011 a series of training schemes also on post-harvest rice management. The IP together with the university developed a standard training module which was then offered through various NGOs and public service agencies;

- the IP further identified choice of variety and seed quality as factors in rice quality. These were found by the $\mathrm{Ph} . \mathrm{D}$. student to be affected by the annual floods in the inland valleys that occur every year from July to September. In 2011 and 2012 flooding was especially severe. Rice farmers themselves made a range of responses to these conditions (Totin et al., 2014b). The IP for its part began to collaborate with field-based service organizations and rice scientists to identify the varieties suited to the different soil-water conditions through the valleys, and to ensure that sufficient quality seed for the selected varieties was available, on time and at an affordable price, to rice farmers.

\section{Discussion}

\subsection{Causality and typology}

There are three main approaches to analysing causality. Firstly, there is co-variation or 'successionist regularities', where a vital causal agent is identified through statistical analysis structured around treatments or variables (Ahn and Kalish, 2000). The correlations that are discovered are taken to be, by inference, causal. However, there is no factual observation of the actual processes. Secondly, generationist mechanisms [hidden mechanisms] also offer an approach to analysing causality (Dalkin et al., 2015). New institutional economics typically adopts this approach. Here measured patterns and uniformities are brought about by action of some 'underlying' mechanisms. But these mechanisms are themselves not always directly measurable. A key question is: why does the measured/observed regularity turn out as it does? The answering explanatory frame is that of underlying 'generative mechanisms'. Thirdly, there is the configurational approach in which causal power is held to be combined in mixes with identifiable attributes that condition what happens (Rihoux and Ragin, 2009). Social theory is vague about how causal conditions combine to produce outcomes. In general, it does not deal well with combinatorial complexities. Thus, it resorts to 'explanatory typology' [as in this paper] that recognises multi-finality and contingency. 
The rationale for our paper derived from the recognition that the COS-SIS studies and data suggested a preponderance of co-operative influences, and a lot of inter-dependence. Little evidence had been recorded of explicitly hostile, purposefully antagonistic or directly competitive relations between the IPs and external actors and influences. But, there was hard questioning as to what this might imply: were the IPs really operating in very cordial and stable contexts favourable to institutional and socio-technical innovations? To find answer (s) there was the need to take up the challenge of analyzing external influences on the IPs.

An important reason also for the analysis of the external influences on the IPs is the interest of contributing to policy making. Analysing causation in a constructive manner is relevant to policy making. Policy makers tend to view policyled change as a process of mutual simultaneous shaping. More recently, expectation has grown that 'meta analysis of mega data' can sort out cause and effect in ways that isolate or remove the confounding effects of external factors. However, this expectation is proving unsatisfactory because it does not tell us what is and is not working in real time. There is a move back toward qualitative research that traces interactive causal processes and mechanisms and of research serving a heuristic function (Donmoyer, 2012). The application of a typology in a constructive manner is useful in providing appropriate policy options.

Other authors have made similar typologies. For example, Arts et al. (2006) suggest a diagram of interactive relationships [shown by lines] among three influences:

- actors and coalitions;

- rules;

- resources.

There are interactive relationships also among each of these three and discourses [which they place at the centre of the triangle of relationships]. Policy decisions and practices are the concrete outputs from the interactive relationships (Arts et al., 2006). Typologies provide analytical tools in understanding identifiable phenomena.

Our typology is meant to illustrate how external influences from the global arena, the continent or sub-region and the national context impact on the IPs. On the question of "what counts as context?', there is no certain way to define how wide the boundaries should be drawn in time and space, beyond the focus of interest of the actors concerned. There is also the other question of 'how to establish that the context is causal?'. Anderson and Scott (2012) suggest reliance on research that produces a 'preponderance of evidence' generated by mixed methods [including participatory research]. In our analysis, we depended on the research conducted on the IPs in the three countries of the COS-SIS programme.

As we proceed to apply our typology, we acknowledge the limitation of the typology. It is that, a typology presents a snapshot of regularities and patterns, and thus tends to 'freeze' the dynamic processes it seeks to reveal. However, a typology of external influences that are interactive and dynamic should not be static or frozen. It should ideally serve like the lenses of a video camera to determine the impacts of the influences across time. It is not possible as the analysis can only be with reference to a particular time, place and the prevailing external influences.

\subsection{External influences}

The analysis in this paper suggests three significant insights:

- the timing, intensity and duration of external influences cannot be controlled by IP members;

- these influences are experienced in combination, and not as discrete events;

- the combination of internal and external influences - pulling in the same or different directions - may either open or close opportunity for socio-technical and institutional change.

The challenge for IPs is how in any particular context they then respond - are they alert to emergent opportunity? Or is their ambition to innovate constrained unduly by influences they regard as in some way dangerous to their own interests and objectives? How do they find their pathway amidst the perceived pressures?

There appears to be a particularly close connectivity between the influences emanating from the political and the economic spheres. In many ways, this can be understood as a simple consequence of the extent to which personalized political institutions in all three countries shape economic policies. The advantage is that political authority can leverage economic activity that opens opportunities for innovations that benefit smallholders. The disadvantage is that political opportunism can encourage economic malpractices, such as rent-seeking or corrupt behaviour on the part of those walking the corridors of power. This poses both practical challenges and a need for ethical reflection by an IP, whose members must work with those in power (at least at local government levels) and who may find it necessary to try to influence those in power at the highest level. Klerkx et al. (2013) suggest that in such circumstances, IPs are able to realize socio-technical and institutional innovation by working with champions of various kinds.

\subsection{IPs' responses}

Nonetheless, in all the three countries, over the time period studied it was political influences that precipitated effects in other spheres. Organisations and individuals in political positions may exert significant influence within a domain but they, too, are subject to kalaediscopic changes following elections or a coup d'état. The COS-SIS experience suggests that enduring institutional innovation can be accomplished, even in these circumstances, when an IP is able to respond effectively to the dynamic politics of power. At the start of the IPs' experience, it was the collective opinion that the membership of 'high level' and politically well connected individuals would be detrimental to the IPs' independence and legitimacy. However, they found that, once they had established their own standing, initial accomplishments, and evidence-based proposals for change, it was beneficial to invite onto the IP a high profile official or politically well-connected individual who was willing to network discretely to push the change process forward.

The effects of political events cannot be anticipated. For instance, when in 2012 the decision was taken to make the 
district representatives of the President of Ghana, the District Chief Executives (DCEs), responsible for overseeing the distribution of agro-chemical inputs in the cocoa-growing areas, the local results were either positive or negative, depending on how each DCE approached this responsibility (Adu-Acheampong et al., 2017). DCEs could use the power of distribution to favour political friends or to undermine the influence of perceived opponents. The history of the governance of cocoa in Ghana reveals how important politically-sensitive decisions, responses and consequences can be (Essegbey and Ofori-Gyamfi, 2012). As Loorbach (2010) puts it, governance issues are not independent of the surrounding environment.

The IPs' responses to socio-cultural influences are also noteworthy. Socio-cultural influences are embedded and therefore cannot be seen as external to the IPs but rather as something that shapes, consciously or not, how an IP sets about its work and its responses to other influences. For instance, women's roles in all three countries traditionally often are secondary to men's. The IP members learned collectively that it takes a conscious and deliberate effort to engage in institutional change to address such deep-seated socio-cultural influences (Zannou et al., 2012).

How an IP is constituted, whether positioned in a niche or operating at national level, also offers lessons for effectiveness. The IPs were strategic in composing their memberships. They did not set out to be 'representative' and are best seen as coalitions of the willing who were able and willing to commit to acting to effect changes that benefited smallholders within their respective domains. As an IP's agenda developed, and the members learned more about the functioning of their domain, or as the political context changed, memberships were adjusted.

However, not all IPs' responses were effective. In Mali, for example, the political upheaval was simply beyond the capacity of the IP to cope. It suspended its operations for a considerable period (which in itself is a response but not effective in addressing the core institutional challenges in the domain). Investors in IPs should be aware of the risks of such 'over-turning' events, and thus realistic in their appreciation of the contribution an IP could make in a given context.

\section{Conclusion}

External influences have been shown to be important in determining the direction of socio-technical and institutional innovation. However, IPs are not entirely the 'puppets of chance' and must not undertake actions without seriously pondering over the options for responses and determining the choice of appropriate response(s). They can enhance the effectiveness of their responses to external influences in a number of ways, given an alert and sufficient appreciation of what is happening in the world around them. IPs must necessarily assess the options for responses - politically, economically, socio-culturally, technologically and environmentally to address institutional constraints. Whilst some options can be very effective in meeting the respective constraints, others may be limited in providing solutions.

The COS-SIS programme's initial presumption that an IP, as an institutional intervention, could be (co) causative in socio-technical and institutional innovation, also seems to be validated - as long as attention is paid to the important notion of co-causality and co-evolution of processes of change in contexts subject to powerful or subtle, transitory or deepseated external influences. The reality of addressing institutional constraints for any IP is that, the IP has to contend with external influences that it has the least control of, if any. To be effective, the IP's responses must therefore be calculating and deliberative taking account of the realistic options open to the IP.

\section{References}

Adjei-Nsiah S, Adu-Acheampong R, Debrah K, Dembelé F, Lassine $\mathrm{S}$, Ouologuem B, et al. 2013. Defying the pervasive bias against African smallholders: identifying entry points for institutional change. Development in Practice 23(7): 843-856. Available from: https://doi.org/10.1080/090614524.2013.811220.

Adjei-Nsiah S, Klerkx L. 2017. Innovation platforms and institutional change: the case of small-scale palm oil processing in Ghana. Cahiers Agricultures 25(6): 9 p. (ISI, Q4) 17. DOI: 10.1051/cagri/ 2016046.

Adjei-Nsiah S, Sakyi-Dawson O, Kuyper TW. 2012. Exploring opportunities for enhancing innovation in agriculture: The case of oil palm production. Ghana Journal of Agricultural Science 4 (10): 212-233.

Adu-Acheampong R. 2013. The role of an Innovation Platform in the governance of smallholder cocoa production in Ghana. Paper presented at CTA/CoS-SIS Expert Consultation, held in Wageningen, February 4-6, 2013. Available from: https://publications. cta.int/media/publications/downloads/1829 PDF.pdf.

Adu-Acheampong R, Jiggins J, van Huis A, Cudjoe AR, Johnson V, Sakyi-Dawson O, et al. 2014. The cocoa mired (Hemiptera: Miridae) problem: evidence to support new recommendations on the timing of insecticide application on cocoa in Ghana. International Journal of Tropical Insect Science 34(1): 58-71.

Adu-Acheampong R, Jiggins J, Tei-Quartey E, Karikari-Addo NM, Jonfia-Essien W, Quarshie E, et al. 2017. An innovation platform for institutional change in Ghana's cocoa sector. Cahiers Agricultures.

Ahn W, Kalish C. 2000. The role of covariation vs. mechanism information in causal attribution. In: Wilson R, Keil F, eds. Cognition and explanation. Cambridge, MA: MIT Press.

Anderson GL, Scott J. 2012. Toward Intersectional Understanding of Process Causality and Social Context. Qualitative Inquiry 18(8): 674-685.

Arts B, Leroy R, van Tatenhove J. 2006. Political modernisation and policy arrangements: A framework for understanding environmental policy change. Public Organisational Review 6: 93-106.

Beuret JE, Dufourmantelle N, Beltrando V. 2006. Les évaluations des processus de concertation: RELIEF, une démarche des outils. Paris: La Documentation française / ministère de l'Écologie et du Développement durable.

Beach D, Pedersen RB. 2013. Process-Tracing Methods Foundations and Guidelines. Ann Arbor: The University of Michigan Press.

Blatter J, Haverland M. 2014. Case Studies and (Causal) Process Tracing. In: Engeli I, Rothmayr CR, eds. Comparative Policy Studies. Conceptual and Methodological Challenges. Houndsmills Basingstoke: Palgrave Macmillan.

Dalkin SM, Greenhalgh J, Jones D, Cunningham B, Lhussier M. 2015. What's in a mechanism? Development of a key concept in realist evaluation. Implement Sci 10: 49. DOI: 10.1186/s13012-015-0237-x. 
Dobrov DM. 1979. The strategy for organized technology in the light of hard-, soft-, and org-ware organization. Long Range Planning 12(4): 79-90.

Donmoyer R. 2012. Can qualitative researchers answer policymakers' What-Works Question? Qualitative Inquiry 18(8): 662 673.

Douglas M. 1986. How Institutions Think. Syracuse, NY: Syracuse University Press.

Essegbey GO, Ofori-Gyamfi E. 2012. Ghana Cocoa Industry - An Analysis from the Innovation System Perspective. Technology and Investment 3: 276-286.

Falleti TJ, Lynch JF. 2009. Context and Causal Mechanisms in Political Analysis. Comparative Political Studies 42: 1143-1166.

Faure G, Gasselin P, Triomphe B, Temple L, Hocdé H. 2010. Innover avec les acteurs du monde rural: la recherché-action en partenariat. Versailles : Quae, CTA, Presses agronomiques de Gembloux.

Geels FW. 2002. Technological transitions as evolutionary reconfiguration processes: a multi-level perspective and a case study. Research Policy 31: 1257-1274.

Geels FW. 2004. From sectoral systems of innovation to socio-technical systems: insights about dynamics \& change from sociological and institutional theory. Research Policy 33(6/7): 897-920.

Hall A, Janssen H, Pehu E, Rajalahti R. 2006. Enhancing agricultural innovation: How to go beyond the strengthening of research systems. Washington DC: World Bank.

Hawkins R, Heemskerk W, Booth R, Daane J, Maatman A, Adekunle AA. 2009. Integrated agricultural research for development (IAR4D): A concept paper for the Forum for Agricultural Research in Africa (FARA) Sub-Saharan Africa Challenge Programme (SSACP). Accra: FARA. Available from: https://assets.publishing.service.gov.uk/me dia/57a08b7ced915d622c000cf7/IAR4D_concept_paper.pdf.

Hounkonou D, Kousssou D, Kuyper TW, Leeuwis C, Nederlof ES, Röling, et al. 2012. An innovation systems approach to institutional change: smallholder development in West Africa. Agriculture Systems 108(2012): 74-83.

Jiggins J. 2012. Diagnostic research in support of innovation, The Netherlands Journal of Life Sciences (NJAS) 60-63: 115-121.

Jiggins J, Hounkonnou D, Sakyi-Dawson O, Kossou D, Traoré M, Röling N, et al. 2016. Introduction: Innovation Platforms to support smallholder development - experiences from sub-Saharan Africa. Cahiers Agricultures 25(6). DOI: 10.1051/cagri/2016051.

Klerkx L, Adjei-Nsiah S, Adu-Acheampong R, Saïdu A, Zannou E, Soumano, et al. 2013. Innovation platforms through an innovation platform lens. An analysis of three cases in West Africa. Outlook on Agriculture 42(3): 185-192.

Kossou D. 2012. Pour relever des défis dans trois secteurs agricoles. Le programme CoS-SIS au Bénin. Les Nouvelles du jour 018: 3, vendredi 11 mai.

Leeuwis C, Van Den Ban A. 2004. Communication for rural innovation: Rethinking agricultural extension. 3rd ed. Oxford: Blackwell Science.

Loorbach D. 2010. Transition management for sustainable development: a prescriptive, complexity-based governance framework. Governance: An International Journal of Policy, Administration and Institutions 23(1): 161-183.
Nederlof ES, Pyburn R, eds. 2012. One Finger Cannot Lift a Rock: Facilitating innovation platforms to trigger institutional change in West Africa. Amsterdam: KIT Publishers.

Nederlof ES, Wongtschowski M, van der Lee F. 2011. Putting heads together: Agricultural Innovation platforms in practice. Amsterdam: KIT Publishers.

North D. 1990. Institutions, Institutional Change and Economic Performance. Cambridge: Cambridge University Press.

Osei-Amponsah C. 2013. Improving the quality of crude palm oil: Transdisciplinary research on artisanal processing in Kwaebibirem district, Ghana, PhD thesis. Wageningen, The Netherlands: Wageningen University.

Quarmine W, Haagsma R, Sakyi-Dawson O, Asante F, van Huis A, Obeng Ofori D. 2012. Incentives for cocoa bean production in Ghana: Does quality matter? Netherlands Journal of Life Sciences (NJAS) 60-63: 7-14.

Rihoux B, Ragin CC. 2009. Configurational Comparative Methods Qualitative Comparative Analysis (QCA) and Related Techniques. Applied Social Research Series, volume 51. Los Angeles: SAGE Publications Inc.

Röling N, Hounkonou D, Kossou D, Kuyper TW, Nederlof S, SakyiDawson O, et al. 2012. Diagnosing the scope for innovation: linking smallholder practices to institutional context. Netherlands Journal of Life Sciences (NJAS) 60-63: 1-6.

Saidou A, Totin E, Kyera GN, Kossou D. 2012. Institutional Experiment on the rice value chain in Southern Benin. In: van Huis A, Rolings N, Hounkonnou D, Youdeowei A, eds. Reflections and Anticipation: Opportunities created by CoS-SIS Programme, Proceedings of the CoS-SIS Cotonou Workshop, pp. 58-60.

Sidibé A, Vellema S, Dembelé F, Traoré M, Kuyper TW. 2017. Analyse d'une plateforme d'innovation dans la filière karité au Mali. Cahiers Agricultures, soumis.

Totin E, van Mierlo B, Saïdou A, Mongbo R, Agbossou E, Stroosnijder S, et al. 2012. Barriers and opportunities for innovation in rice production in the inland valleys of Benin. Netherlands Journal of Life Sciences (NJAS) 60-63: 57-66

Totin E, Leeuwis C, van Mierlo B, Mongbo R, Stroosnijder L, Kossou D. 2014a. Drivers of cooperative choice: canal maintenance in smallholder irrigated rice production in Benin. International Journal of Agricultural Sustainability 12(3): 334-354.

Totin E, van Mierlo B, Mongbo R, Leeuwis C. 2014b. Diversity in success: interaction between external interventions and local actions in three rice farming areas in Benin. Agricultural Systems. Available from: https://doi.org/10.106/j.agsy.2014.10.1012.

Williamson O. 2000. The New Institutional Economics: taking stock, looking ahead. Journal of Economic Literature 38(3): 595-661.

Zannou E, Soumano L, Adjei-Nsiah S, Ouloguèm B, Kossou D, Klerkx L, et al. 2012. 'Analysing power relationships in 'Concertation and Innovation Groups' in nine agro-enterprise domains in Ghana, Benin and Mali'. Paper presented at 19th Annual Conference on Multi-Organisational partnerships, Alliances and Networking, July 2-4 Wageningen, The Netherlands. In: MOPAN (2012) Proceedings: Multi-actor Collaboration in an Uncertain and Ambiguous World, Wageningen, The Netherlands.

Cite this article as: Essegbey GO, Sakyi-Dawson O, Kossou D, Ouologuem B, Dembele F, Adu-Acheampong R, Jiggins J. 2017. External influences on agro-enterprise innovation platforms in Benin, Ghana and Mali - Options for effective responses. Cah. Agric. 26 : 45011. 